\title{
Women on the Road: Women in Patriarchal Society in Sense and Sensibility
}

\author{
Weigui Zhou ${ }^{1}$ \\ ${ }^{1}$ School of Foreign Languages, China West Normal University, Nanchong, China \\ Correspondence: Weigui Zhou, School of Foreign Languages, China West Normal University, No. 1, Shida \\ Road, Shunqing District, Nanchong, 637009, China. E-mail: a2001-1982@sohu.com
}

Received: June 27, 2016 Accepted: July 20, 2016 Online Published: August 28, 2016

doi:10.5539/ells.v6n3p70 URL: http://dx.doi.org/10.5539/ells.v6n3p70

\begin{abstract}
Jane Austen's Sense and Sensibility is a drama about women's love and marriage. She translates women's fates in her time into her novel. In her novel, women are not socially independent and the problem of sense and sensibility is not rightly handled. Women, especially those young unmarried women, are just traveling on the road with marriage as their destination. Women's education leads them to develop in sensibility and utilitarianism. Austen firmly believes that women, in order to maintain their selves, must cultivate their sense. To make a perfect marriage, women should consider not only money, but also love. This paper is a brief discussion about Austen's treatment of women in Sense and Sensibility.
\end{abstract}

Keywords: Sense and Sensibility, selfhood, marriage of convenience, humor

\section{Introduction}

Jane Austen (1775-1817) is best remembered for her minute record of the commonplace life of the people in her age. All through her life, Austen produced six novels, including Pride and Prejudice, Sense and Sensibility, Emma, Northanger Abbey, Mansfield Park, and Persuasion, all of them fine examples of the middle class life. These works secured for Austen a firm place in English literature. F. R. Leavis traced in his The Great Tradition (2002) the development of English novels and picked out some novelists as the greatest novelists, who stand for the development of novels. In Leavis's opinion, Jane Austen was the first great novelist in tradition. Critics have profoundly examined Austen's novels from various perspectives and Austen has continuously inspired generations of readers because of her skillful treatment of such topics as love, marriage and life. Austen has also influenced many following writers in that "She was the founder of the novel which deals with unimportant middleclass people and of which there are many fine examples in latter English fiction." (Wu, 1988, p. 118)

Jane Austen's Sense and Sensibility, published in 1811, is a novel which dramatizes the fate of women in the patriarchal society. The novel was first entitled as Elinor and Marianne, and it was Austen's first published novel. The plot of this work revolves around a contrast between Elinor's sense and Marianne's emotionalism, as the title would suggest. This popular novel has been adapted for film and theater and it remains one of Austen's finest novels. Though it narrates a love story between two sisters, it profoundly uncovers the social injustice and prejudice against women. Many critics have analyzed this novel from the feminist perspective, and Austen's employment of humor and skillful mastering of language are also carefully investigated by critics. This thesis tends to analyze women's fate from the feminist perspective by combining the text analysis and the background of the age when Austen wrote this novel.

\section{Women and Marriage in Sense and Sensibility}

\subsection{The Deprivation of Women's Right of Inheritance}

In Austen's time, women were not socially independent. They had to comply to their father, and, after the death of their father, they had to rely on their brother for protection. In a society where the value of the system of primogeniture was highly respected, women had no right to inherit all real property. Even if the family produced no male heir, the property of the family may went to the daughters' male cousin after the death of the father. In order to live, they must receive protection from their brothers. But after their brothers' marriage, women served no longer as their brothers' sister, but as an intruder to the newly married couple. For these women who enjoyed no real property, marriage was their destination. Only after they secured a wealthy husband can they live a 
comfortable and comparatively sufficient life.

Directly after Mr. Henry Dashwood's death, Elinor, Marianne and Margaret, as well as their mother, become visitors to Norland Park where they once lived happily. The estate now goes to their half-brother Mr. John Dashwood. The Norland Park no longer belongs to them, and they are treated as visitors by their "kind" brother and especially their sister-in-law. They have to find another place to live. Fortunately they are offered a residence at Barton Cottage, which is far from Norland Park, at low rent by their mother's relative. So they begin their travel to Barton Cottage where they will live. It seems that they will live independently there since they at least pay for the house. Both Elinor and Marianne are glad that they will not receive their brother's cold shoulder again. But problems emerge directly after their settlement at Barton Cottage. Elinor is quite aware of this problem - the management of the house. Marianne doesn't notice this problem, and even their mother is not fully aware of this problem. In this male world, they have no income except the interest of their ten thousand pounds. It isn't a large sum of money for the four women to live on. So Elinor must be prudent in dealing with their small income. It's hard to imagine that the four women would live on the ten thousand pounds for a whole life. Marriage is the only way out! To marry a wealthy man means that they can earn a living.

\subsection{Women's Odyssey in Search of Wealthy Husbands}

In fact, the heroines' experiences in this novel can be viewed as an odyssey in search for fulfillment. After the death of Mr. Henry Dashwood, the Dashwood sisters are on their aimless journey. They go to live in the Barton Cottage, but they belong not there. They are just guests with small property. The Barton Cottage can't be their permanent home and it is impossible for these women to live there permanently. The two elder sisters' journey to the town is a journey in search for good luck. They are restless "on the road" and expectant for meeting their lovers. Marianne's pursuit of romantic love ends up in despair. Fortunately under Elinor's help, she recovers from her infirmity and earns her true love at last. Elinor, after experiencing some disappointments, finally takes the hands of Edward in marriage. Their marriage is a turning point for their life, for they will not stray around again. They finally earn their home and become settled.

LeRoy W. Smith writes in Jane Austen and the Drama of Woman as follows: "In patriarchy, concern for the disposition of property rules the making of marriages. In nineteenth-century England middle-and-upper-class women had little choice but to place themselves on the market in hope of attracting a bidder." (Smith, 1983, p. 14) Marriage becomes a form of "legalised prostitution" because it is a kind of give-and-take business. To live a better life women have to capture a wealthy husband, namely, to seek a marriage of convenience. There is no love between wives and husbands in many marriages. The man just needs a woman to manage the household and bear children. The woman just wants to find a ticket in marriage by which she will enjoy a wealthy life. Dances provide women with a superexcellent choice for hunting a spouse. Various dances are only a place which can be called a marriage marketplace. After marriage, these wives serve as housekeepers and child-bearer. They lose their selfhood and live a life dependent upon their husbands. What readers can find in these women's marital life is subjugation and depersonalization. They can no longer be called complete human beings.

Elinor's brother John Dashwood guesses that Elinor have an affair with Colonel Brandon and he tries to persuade her to secure Brandon as her husband. As a brother, he gives nothing to his sisters, but in order to make up to Elinor, he pretends that he is worried about his sister's happiness. His persuasion is that Elinor should marry Brandon because Brandon is a man with large property. He is "resolved on seeking an intimacy with that gentleman, and promoting the marriage by every possible attention". (Austen, 1994, p. 199) John Dashwood openly encourages Elinor to pursue a marriage of convenience only because it is a business with much benefit.

\subsection{Examples of Marriage of Convenience}

The best specimen of women seeking a marriage of convenience is Lucy Steele. She is a woman with small fortune. Thus, she knows what women are supposed to do in this patriarchy society. Marriage, for her, is nothing but a beneficial trade. She must have known Edward's affection towards Elinor. So she exposes her secret engagement with Edward to Elinor, the purpose of which is, without doubt, to make sure that her Edward should not be taken away from her. Edward is her passport for a wealthy future. Though she tells Elinor that their affair is real love, readers still can sense her real purpose in her own words. After Edward is deprived of the right to inherit his family property, Lucy soon focuses her attention on Robert who has inherited what originally had belonged to Edward. Her skill at capturing a husband is unparalleled. Her pretext is that Edward no longer loves her and she can't "accept a hand while the heart was another's" (Austen, 1994, p. 320). She is really very persuasive in her goodbye letter to Edward. She has known Edward's affection towards Elinor for a long time. Since Edward now loses his property, it is no longer necessary to continue her engagement with Edward because her ticket is in Robert's hands now. But her marriage with Robert is not a reciprocal one, since no love exists 
between them.

Another case of marriage of convenience is the marriage between Charlotte and Mr. Palmer. Mr. Palmer is a typical middle-class man, pretentious, self-important and rude, while Charlotte is a talkative, shallow woman with no taste. Their marriage, it is certain, is not a marriage out of love. Presumably she marries Mr. Palmer only for his wealth. In this patriarchal society, a good marriage, to a middle-class woman, is a marriage of their wealth and their status. Their lives are not bound together by love, but by needs. Thus, "Charlotte laughed heartily to think that her husband could not get rid of her; and exultingly said, she did not care how cross he was to her, as they must live together." (Austen, 1994, p. 96) She openly confesses that "Mr. Palmer does not hear me..." (Austen, 1994, p. 92). They have no mutual understanding between each other. Like sand and grain mixed together, they can never achieve mutual communion. However, Charlotte never stops laughing everyday because she knows that Mr. Palmer can not get rid of her. Her place as an "important" Mrs. Palmer is secured. Charlotte's confidence rises from her distorted view about marriage.

Austen's heroines will not marry except for love. "They achieve the relationship of reciprocal giving and receiving within a loving, caring marriage which is vital to happiness." (Smith, 1983, p. 44) "Austen sees 'acceptable' courtship as one in which the parties are 'well suited' to each other and one that leads to marriage." (Bochman, 2005, p. 5) Thus, Elinor's and Marianne's marriages are real marriage. In their marriage, equality is the key to their happiness. Their marriages are not based on money but on love, thus they are not marriages of convenience. In Austen's eyes, though marriage can not leave the question of money untouched, it is love that makes a real marriage. This marriage will not cost the heroine of her selfhood. On the contrary, their marriages are marriages where assertion of self is preserved. They gain mutual understanding with their husband. There is no doubt that Austen values these real marriages and despises these marriages of convenience.

\section{The Relationship between Mother and Daughter in Marriage Market}

\subsection{Mother as the Moral Teacher in the Daughters' Pursuit of Marriage}

Sense and Sensibility is a novel about middle-class women in which Jane Austen not only discusses the relationship between men and women, but also the relationship between mothers and daughters. Those daughters in this novel no longer enjoy protection from the father. Though Elinor's father, Mr. Henry Dashwood, doted on his daughters, his untimely death throws his daughters into the world. His expectation that Mr. John Dashwood should take care of his daughters fails. As a mother of three daughters, Mrs. Henry Dashwood should have taken the responsibilities to provide protection for her daughters. However, Mrs. Dashwood is a foolish woman, though she loves her daughters.

In this patriarchal society, mother serves as the daughter's moral teacher. As women themselves, many of them know how important marriages are to their daughters. Thus, many mothers "train daughters to capture a husband rather than to attain their fullest personal development..." (Smith, 1983, pp. 30-31) These mothers will train their daughters to manipulate the marriage market to one's own advantage. Mrs. Jennings is such kind of mother. She believes herself successful because her daughters are both well married. They are both married to well-bred middle class men who enjoy large properties. She says to Mr. Palmer: "Aye, you may abuse me as you please, you have taken Charlotte off my hands, and cannot give her back again. So there I have the whip hand of you." (Austen, 1994, p. 96) In her eye, Charlotte is Mr. Palmer's property. Since they have married, Mr. Palmer is responsible for Charlotte's well-being.

\subsection{Mrs. Dashwood's Impotency}

Another mother in this novel is Mrs. Dashwood. Comparatively speaking, Mrs. Dashwood is impotent. In the Dashwood family, the one who really plays the role of mother is Elinor. Like Marianne, Mrs. Dashwood is too sensitive rather than sensible. She would have quitted the Norland Park directly after the arrival of Mr. and Mrs. John Dashwood, had not the entreaty of Elinor forced her to stay. She totally dislikes her selfish daughter-in-law. But she and her three daughters have to endure the unkindness of Mrs. John Dashwood for a while, because they have no other place to go. Elinor knows their situation quite well and it is she who keeps the balance between the couple and the four unfortunate women. After Willoughby and Marianne falls in love with each other, Mrs. Dashwood surely will accept Marianne's entreaty that they will keep the horse Willoughby gives her. But Elinor persuades her sister to give up this idea, because they can not afford to have a horse. It is Elinor who serves as the real "mother" in the house. She manages the house and provides protection for her mother and sisters.

Mrs. Dashwood, at the same time, takes little notice of her would-be son-in-law's property. When she knows that Elinor and Edward have mutual affection for each other, she looks forward to their marriage not because Edward will have large property, but because Edward appears to love her daughter and her daughter returns his partiality. 
Thus, she does not stop Marianne when Willoughby courts Marianne, though he has no large property. She does not want to meddle with her daughter's love affair. But Elinor is constantly worried about her sister's love affair. She even asks her mother to make sure whether they are engaged or not. Here Elinor is the real mother of the house rather than Mrs. Dashwood.

\section{Sense and Sensibility in Women's Pursuit of Marriage}

\subsection{Stereotype of Women: Irrational and Sensitive}

What Elinor and Marianne behave in the novel is a full interpretation of the novel's name-Sense and Sensibility. Austen assigns "sensibility" to the younger sister, Marianne, while she depicts "sense" as the prominent character of Elinor. In Austen's fictional world, Elinor is an ideal woman who embraces not only sensibility but also sense. As for sense and sensibility, which one is more important for a woman? Austen believes that sense is more important for a woman if she wants to live independently.

The stereotypes of male and female personality are different: "The categories of 'masculine' and 'feminine' are exclusive, contradictory and polar...The masculine stereotype includes aggressiveness, competitiveness, rationality, analytic ability, objectivity, emotional control, activity, intelligence, independence, confidence and self-sufficiency, linked to consciousness and tending to construct boundaries between the self and the 'other'. The feminine stereotype includes passivity, irrationality, emotionality, empathy and adaptability, linked to unconsciousness and tending to reduce boundaries between the self and the "other"' (Smith, 1983, pp. 11-12).

Women are thought to be irrational and emotional beings. They are not intelligent enough to be involved in politics and economics. Thus, for women "the primary role was child-bearing and care of the family, whereas for men it was providing for the family's well-being" (Smith, 1983, p. 11). Since men provides for the family's well-being, men's role is thought to be superior while women's role inferior.

Women's education is also under attack by some scholars, Wollstonecraft, for example. "Her principal target was women's education, which failed to develop their capacities or interests. It should be equal to and identical to men's, and it should help women develop the ability to think rationally." (Smith, 1983, p. 16) Women, in Wollstonecraft's and Austen's eyes, should be rational beings, and can be trained to think rationally.

\subsection{Marianne: Specimen of Women with Too Much Sensibility}

Marianne is a typical specimen of one with too much sensibility. Her mother serves as her moral teacher. Mrs. Dashwood is also a woman with too much sensibility and little sense. Marianne sheds too much tears on her leaving the Norland Park, because those things even including the trees in the park she loves so greatly. She is so urgent to confess her love that she is easily cheated by Willoughby. She openly talks about what and who she likes or dislikes. And she refuses to be together with those people she hates, even though those people may be her brother and sister-in-law. She dislikes Mrs. Jennings, but she ventures to travel to the town with Mrs. Jennings just because she would have the opportunity to meet Willoughby again. On approaching the town, her heart is occupied by nobody else but that dandy playboy. After they arrive at Mrs. Jennings' home, she spends day after day waiting for the coming of Willoughby. Regardless of what the other people would think of her, her expression of feeling is "excruciatingly dramatized as Marianne insists on claiming intimacy with Willoughby in a crowded ballroom" (Brownstein, 2001, p. 44). After her discovery of what Willoghby have been doing after they separated, she washes her face with her tears everyday. In her eye, the whole world collapse. If not for the help of Elinor, she would have no willpower to live so miserably. Her sensibility nearly costs her life. In this patriarchal society, romantic love must be based on the equality between men and women. If not, "clinging to romantic ideals becomes self-destructive" (Buss, 2004, p. 9). To achieve this equality, one must be economically independent. Edward Copeland writes, "The heartbeat of romance lies in a good income." (Copeland, 2001, p. 132) Marianne's vision of love is only a mirage because she is too ready to take everything for granted. She trusts her feelings to guide her conduct and ignores conventions and those common-place jokes. She believes in "first and passionate love, a meeting of tastes and minds" (Brownstein, 2001, p. 43). If she failed, her misery doesn't undergo necessary check by her rationality. Thus, her loss would be even greater than she can bear. Fortunately, she has a considerate sister to lead her through difficulties.

\subsection{Elinor: Embodiment of Both Sense and Sensibility}

Elinor, on the contrary, is a lady with sensibility and, most importantly, sense. She loves Edward deeply, though she does not openly confess her affection. Her love is a love of giving. When she knows that Edward is engaged to Lucy, she represses her pain and carries on bravely. She understands what Edward has done for himself. In Marianne's eye, Edward is another Willoughby, but in Elinor's eye, Edward is a real man with responsibility. Her rationality helps her overcome the great difficulty over her loss of Edward. She still loves Edward, but she 
knows there would be no hope for her unless Edward and Lucy get separated. When Edward refuses her mother's plan to marry another rich lady, Elinor sings her praise for Edward. Edward is holding fast to his promise with Lucy. Just for a woman who he really doesn't love, he keeps his responsibility to give up his property rather than break his promise. Elinor feels proud of Edward for what he has done. Elinor is ready to put herself in Edward's position, thus she quite understands Edward's difficulties.

Elinor observes those formalities prescribed in social communication. "Elinor is more circumspect, more aware of how the self interacts with others; in her view, conventions are necessary and even useful." (Brownstein, 2001, p. 43) She tries to be considerate towards the jolly Mrs. Jennings and even her own selfish brother. Heartbroken by the revelation of Lucy's secret, she restrains herself to break out and she does not reveal this news to her mother and sister till Lucy and Edward's engagement is openly spoken by Miss. Steele. Though she feels painful in her heart, she still have to comfort her sister who indulges herself in grieves due to Willoughby's betrayal. After Edward loses his property, Elinor tries to help him get out of the difficulties. Her generosity could have helped Edward and Lucy become well settled if Lucy does not break the engagement. Elinor's prudence can also be perceived through her management of the house. As discussed before, she served as the real mother of the family.

Marianne, fortunately, realized her own fault in dealing with her own feeling at last. She receives Colonel Brandon's offer of love and tries to live a sensible life as her sister does. Sense at last rules out sensibility. But this change is not brought by Mrs. Dashwood's instruction but by Elinor's good example. Without doubt, the marriage between sense and sensibility in her own self will lead Marianne through a happy life in which Brandon and Marianne shared with rather than hunt for each other.

\section{Conclusion}

Jane Austen joyfully narrates those women's stories which may be true in her time. Normally these stories are concerned with love, marriage, and women's fate. However, Austen does not copy these stories in a tranquil mood. She employs a powerful weapon to expose the inequality existing in her time- -humor. Austen's humor is satirical rather than amusing, far-sighted rather than shortsighted. Thus, her humor is a mirror of the reality and she is viewed as a realist by some critics. According to Ian Watt, Jane Austen is a novelist following Richardson in her minute presentation of daily life. He refers to Austen as "first and foremost a critical observer of humanity who uses irony as a means of moral and social judgment." (quoted in Buss, 2004, p. 9) Her irony is not only directed to expose humanity, but also social inequality. But Austen's humor is subtle and her criticism of her society is disguised by her narration and happy ending of the story.

In her minute presentation of daily life, Jane Austen records the inequality between men and women in her age. Many women have no right to inherit properties and their happy life would without doubt lies in their marriage. Marriage is their ticket to a stable and secure life. So women are on the road to secure a wealthy husband if they are not married. As Austen suggests, only sensibility would lead to a disastrous ending in marriage, because the social reality makes "sense" an imperative in a marriage. Thus, to seek fulfillment in a marriage, sense and sensibility are both essential for women to search for their husband.

\section{References}

Austen, J. (1994). Sense and Sensibility. Beijing: Foreign Language Teaching and Research Press.

Bochman, S. (2005). Less Than Ideal Husbands and Wives: Satiric and Serious Marriage Themes in the Works of Jane Austen and Oscar Wilde. Ph. D. Diss. City University of New York.

Brownstein, R. M. (2001). Northanger Abbey, Sense and Sensibility, Pride and Prejudice. In E. Copeland \& J. Mcmaster (Eds.), The Cambridge Campanion to Jane Austen. Shanghai: Shanghai Foreign Language Education Press.

Buss, J. (2004). Challenging Authority through Narration: a Study of the Works of Jane Austen and Kate Chopin. Diss. Truman State University.

Copeland, E. (2001). Money. In E. Copeland \& J. Mcmaster (Eds.), The Cambridge Campanion to Jane Austen. Shanghai: Shanghai Foreign Language Education Press.

Smith, L. W. (1983). Jane Austen and the Drama of Woman. London: The Macmillan Press. http://dx.doi.org/10.1007/978-1-349-17184-2

Wu, W. (1988). History and Anthology of English Literature (Book 2). Beijing: Foreign Language Teaching and Research Press. 


\section{Copyrights}

Copyright for this article is retained by the author(s), with first publication rights granted to the journal.

This is an open-access article distributed under the terms and conditions of the Creative Commons Attribution license (http://creativecommons.org/licenses/by/4.0/). 